\title{
Poultry
}

\section{Effect of different phytases derived from E. coli AppA gene on the performance, bone mineralisation and nutrient digestibility of broiler chicken}

\author{
K. Kozlowski ${ }^{1}$, L. Nollet ${ }^{2}$, A. Lanckriet ${ }^{2}$, E. Vanderbeke ${ }^{1}$, P. Mielnik ${ }^{1}$, N. Outchkourov ${ }^{3}$ and S. Petkov ${ }^{3}$ \\ ${ }^{1}$ University of Warmia and Mazury, Department of Poultry Science, Olsztyn, Poland \\ ${ }^{2}$ Huvepharma NV, Antwerp, Belgium \\ ${ }^{3}$ Hwepharma EOOD, Sofia, Bulgaria
}

\section{Abstract}

This study evaluated the effects of three different thermostable phytase variants, based on the AppA gene from E. coli (AppAT1, AppAT2 and AppAT3) on growth performance, nutrient digestibility and bone mineralisation in broiler chickens at inclusion levels of 250 and $500 \mathrm{FTU} / \mathrm{kg}$. The eight treatment groups included a positive control (PC) which was sufficient in $\mathrm{Ca}$ and $\mathrm{P}$, a negative control (NC, the same basal formulation as the PC, but reduced in Ca and P), and NC supplemented with AppAT1 at 250 and 500 FTU/kg (AppAT1-250 and AppAT1-500), AppAT2 at 250 and 500 FTU/kg (AppAT2-250 and AppAT2-500) and with AppAT3 at 250 and 500 FTU/kg (AppAT3-250 and AppAT3-500). Over the entire feeding period, body weight $(\mathrm{BW})$ and average daily gain (ADG) were significantly higher in the PC group, with all phytase supplemented groups being statistically the same, compared to the NC group. Feed conversion (FCR) for the PC-fed birds (1.479) was significantly $(\mathrm{P}<0.05)$ better compared to the NC birds (1.582) and those fed the AppAT3-250 diet (1.523). Reduced levels of Ca and $\mathrm{P}$ in the NC group led to significantly $(\mathrm{P}<0.05)$ lower tibia ash $(40.9 \%)$ compared to the PC group $(47.4 \%)$. Birds fed the phytase diets had significantly higher tibia ash compared to the NC birds, with those from the AppAT2-500 and AppAT3-500 groups being statistically the same as the PC group. Diets AppAT1-500, AppAT2-250, AppAT2-500 and AppAT3-500 significantly increased Ca digestibility compared to the NC. Apparent total track digestibility (ATTD) of P was improved for AppAT1-500 and AppAT2-250. The ATTD of $\mathrm{Ca}$ and P for all of the phytase supplemented groups reached the same level of the PC and AppAT1-500 group. It was concluded that adding any of the phytases tested, especially when included at $500 \mathrm{FTU} / \mathrm{kg}$ to a feed reduced in $\mathrm{Ca}$ and $\mathrm{P}$, led to improved performance and bone mineralisation back to the same levels as seen for the $\mathrm{Ca}$ and $\mathrm{P}$ sufficient diet.

Keywords: Phytase: E. coli: broiler: digestibility: phytate

(Received 23 June 2019 - Accepted 14 July 2019)

\section{Introduction}

Phytases have received significant focus from researchers for decades, and have been used commercially since the early 1990s (Cowieson et al., 2011). Phytate is the main storage form of phosphate in plant material. It has antinutritive effects in poultry, because it binds $\mathrm{P}$ and other nutrients and decreases their availability (Cabahug et al.,
1999; Cowieson et al., 2004; Cowieson and Bedford, 2009; Beeson et al., 2017). Ravindran et al. (2000) were one of the first to conclude that the adverse effect of phytic acid could be overcome by supplemental phytase, resulting in improved performance of broilers. In plantderived feed ingredients, phytate can normally be found in concentrations ranging from 5 to $25 \mathrm{~g} / \mathrm{kg}$ (CVB, 2018). 
The phytase enzyme hydrolyses phytic acid to inositol and inorganic $\mathrm{P}$, which results in improved $\mathrm{P}$ utilisation (Singh et al., 2003b). The four possible sources of phytase are intestinal, microbial (from either microflora in the digestive tract or exogenous sources) and endogenous (from plant materials). Research has shown that, although cereals and their by-products can be used in diets as exogenous sources of phytase (Barrier-Gillot et al., 1996), the efficacy of their use is highly variable, as poor heat stability of the enzyme restricts their use, particularly in pelleted diets (Eeckhout and De Paepe, 1996). Additionally, it has been shown that plant phytases have a lower efficacy when compared with microbial phytases from yeast and fungi (Eeckhout and De Paepe, 1994), which are more heat stable and active over a wider $\mathrm{pH}$ range, retaining their activity within the gizzard and proventriculus (Simons et al., 1990). Consequently, microbial phytases are now more commonly used in commercial feeds. The first commercially available phytase was an Aspergillus niger 3-phytase, but in the last two decades newer 6-phytase originating from E. coli, Peniophora, Citrobacter or Buttiauxella spp. have entered the market.

Multiple studies have reported that microbial phytase improves chicken growth performance (Simons et al, 1990; Sebastian et al., 1996; Singh et al., 2003a; Kozłowski et al., 2010; Rutherfurd et al., 2012; Beeson et al., 2017; Dersjant-Li et al., 2018), promotes the digestibility and availability of phytate-bound $\mathrm{P}, \mathrm{Ca}, \mathrm{Cu}$ and $\mathrm{Zn}$ and increases ileal crude protein, amino acid digestibility (Ravindran et al., 2000; Singh, 2008; Rutherfurd et al., 2012) and bone ash (Kozłowski et al., 2009; Leyva-Jimenez et al., 2019). Phytase supplementation has been demonstrated to allow complete, safe and economic replacement of dietary inorganic phosphorus, reducing feed costs by improving FCR (Singh et al., 2003a, b). The effect of supplementing microbial phytase does, however, depend on its inclusion rate, form of the diet, bird age and genotype, and nutrient content of the diet (Singh, 2008). However, it has been acknowledged that the source and level of the phytase in feed can influence the magnitude of responses in poultry, both on performance and bone development (Walk et al., 2018; Leyva-Jimenez et al., 2019; Walk et al., 2019). However, the effect of level, source and granulometry of Ca sources has been shown to have a negative impact on phytase activity (Amerah et al., 2014; Delezie et al., 2015; Dersjant-Li et al., 2018; Kim et al., 2018).

Acceptance of new phytases by the animal industry depends on many factors (Lei and Stahl, 2001). Based on the AppA2 gene from E. coli, several novel phytase variants with highly improved thermal stability have been obtained via protein engineering and analysed in a series of preliminary in vitro experiments to determine their intrinsic heat stability. Of these, three were selected for future evaluation in vivo.

The aim of the current study was to evaluate the performance in vivo of these three novel phytases on growth parameters, digestibility and bone mineralisation in broiler chickens in order to select the most promising variant for further development.

\section{Materials and Methods}

Birds

A total of 1056, one-day-old male Ross 308 broilers obtained from a commercial hatchery in Mońki, Poland were used in the study conducted at an experimental farm near Olsztyn, Poland. The trial was carried out in a commercial poultry house with an artificial lighting program, automated gas heating and forced ventilation. The lighting and heating program were conducted following the recommendations given in the Ross Production Manual (Aviagen, 2014). Temperature from d 1 to $\mathrm{d} 3$ was $29-30^{\circ} \mathrm{C}$ which was lowered to reach $21^{\circ} \mathrm{C}$ at $\mathrm{d} 21$ and then maintained at this temperature until the end of the trial. Chickens were housed in 96 floor pens (measuring $0.7 \mathrm{~m}^{2}$ ), with 11 birds in each pen. Chickens were given ad libitum access to water and feed for the duration of the trial ( 35 days).

\section{Diets and treatments}

Upon arrival at the farm, chickens were randomly allocated to treatments and replicates. There were eight treatment groups, each having 12 pens of 11 birds and providing a total 132 birds per treatment.

Three different phytases were produced by Huvepharma (3a Nikolay Haytov Str., 1113 Sofia, Bulgaria) and named AppAT1, AppAT2 and AppAT3. They were developed from the AppA2 gene derived from E. coli, as described in Rodriguez et al. (1999) and inserted and expressed in Komatagaella phaffii (formerly known as Pichia pastoris). For each phytase, two premixes were prepared using wheat flour as a diluent, to achieve a concentration of either 250 FTU/kg feed or $500 \mathrm{FTU} / \mathrm{kg}$ feed when the premixes were added to the feed at an inclusion level of $500 \mathrm{~g} /$ tonne. The eight treatment groups included a positive control (PC - sufficient in Ca and P), a negative control (NC; formulated in the same way as the PC but reduced in $\mathrm{Ca}$ 
and P), AppAT1-250 (NC + AppAT1 at 250 FTU/kg), AppAT1-500 (NC+ AppAT1 at 500 FTU $/ \mathrm{kg}$ ), AppAT2-250 (NC+ AppAT2 at 250 FTU/kg), AppAT3-500 (NC+ AppAT2 at 500 FTU/kg), AppAT3-250 (NC+ AppAT3 at 250 FTU $/ \mathrm{kg})$ and AppAT3-500 (NC + AppAT3 at $500 \mathrm{FTU} / \mathrm{kg})$.

The composition and nutritional values of the basal diets, fed in pelleted form, are shown in Table 1. All diets met the nutritional requirements for broiler chicks (NRC, 1994) except for $\mathrm{Ca}$ and $\mathrm{P}$ in the NC in grower and finisher. The birds from all treatment groups received the same starter diet until d 5 to avoid early health problems in the NC group which would be expected to occur due to insufficient $\mathrm{P}$ intake. Following this, treatments were imposed as above during the grower and finisher phases. These diets were formulated to differ by approximately $1.5 \mathrm{~g} / \mathrm{kg}$ in available $\mathrm{P}$ between the negative and positive control diets. Grower diets were used from d 6 to 21 and finisher diets from d 22 to 35 (end of the trial).
Proximate analysis was conducted using official methods (AOAC, 2012). Phytase activity was spectrophotometrically conducted by Biovet (Bulgaria) according to phytase assay EN ISO 30024 (2009). Results are indicated in Table 2.

\section{Measurements}

The BW of the birds was recorded per pen at d 1, 5, 21 and 35 of age and ADG was calculated. Average daily feed intake (ADFI) for the starter (d 1-5), grower (d 6-21) and finisher (d 22-35) periods were recorded and used to calculate the FCR. Bird mortality, culls or removals for other reasons were recorded. The BW of dead, culled or removed birds was used to correct the FCR.

On day 21, two birds from each pen, which were closest to the average weight, were euthanised by cervical dislocation. Their right tibias were removed, cleaned and analysed for ash (AOAC, 2012). The tibia samples from the two birds from each pen were pooled before

Table 1. Composition and nutrient density of the experimental diets

\begin{tabular}{|c|c|c|c|c|c|}
\hline \multirow[b]{2}{*}{ Ingredients \% } & \multirow[b]{2}{*}{ Starter (d 1-5) } & \multicolumn{2}{|c|}{ Grower (d 6-21) } & \multicolumn{2}{|c|}{ Finisher (d 22-35) } \\
\hline & & $\mathrm{PC}$ & NC & $\mathrm{PC}$ & $\mathrm{NC}$ \\
\hline Corn & 36.18 & 57.00 & 58.27 & 54.59 & 55.80 \\
\hline Wheat & 25.00 & - & - & - & - \\
\hline Soybean meal & 31.50 & 25.20 & 25.20 & 19.60 & 19.40 \\
\hline Rapeseed meal & - & 10.00 & 10.00 & 15.00 & 15.00 \\
\hline Animal fat (lard) & - & 3.00 & 3.00 & 4.00 & 4.00 \\
\hline Soybean oil & 2.90 & 1.40 & 0.95 & 2.55 & 2.15 \\
\hline Na-bicarbonate & 0.26 & 0.21 & 0.21 & 0.20 & 0.20 \\
\hline Salt & 0.21 & 0.22 & 0.22 & 0.20 & 0.20 \\
\hline Limestone & 1.39 & 1.11 & 1.16 & 0.97 & 1.02 \\
\hline MCP & 1.56 & 0.98 & 0.31 & 0.84 & 0.18 \\
\hline DL-Methionine & 0.24 & 0.18 & 0.18 & 0.19 & 0.19 \\
\hline L-Lysine & 0.18 & 0.17 & 0.18 & 0.26 & 0.26 \\
\hline L-Threonine & 0.06 & 0.03 & 0.03 & 0.06 & 0.06 \\
\hline L-Valine & 0.03 & - & - & 0.05 & 0.05 \\
\hline $\mathrm{TiO}_{2}$ & - & - & - & 1.00 & 1.00 \\
\hline Premix ${ }^{1}$ & 0.50 & 0.50 & 0.50 & 0.50 & 0.50 \\
\hline \multicolumn{6}{|l|}{ Nutrient } \\
\hline $\mathrm{ME}(\mathrm{kcal} / \mathrm{kg})$ & 2851 & 2902 & 2901 & 2951 & 2952 \\
\hline Crude protein $(\mathrm{g} / \mathrm{kg})$ & 214.80 & 204.80 & 204.90 & 193.50 & 193.50 \\
\hline Crude fibre $(\mathrm{g} / \mathrm{kg})$ & 24.20 & 31.10 & 31.20 & 34.50 & 34.60 \\
\hline Crude fat $(\mathrm{g} / \mathrm{kg})$ & 52.20 & 74.20 & 70.30 & 95.00 & 91.50 \\
\hline Crude ash (g/kg) & 60.90 & 54.50 & 48.40 & 61.40 & 55.40 \\
\hline Dig. Lysine (g/kg) & 10.99 & 10.32 & 10.32 & 10.22 & 10.18 \\
\hline Dig. Methionine (g/kg) & 5.15 & 4.69 & 4.69 & 4.69 & 4.70 \\
\hline Dig. Met + Cys $(\mathrm{g} / \mathrm{kg})$ & 8.04 & 7.53 & 7.55 & 7.46 & 7.47 \\
\hline Dig. Threonine $(\mathrm{g} / \mathrm{kg})$ & 7.13 & 6.75 & 6.74 & 6.65 & 6.64 \\
\hline Dig. Valine (g/kg) & 8.78 & 8.25 & 8.25 & 8.14 & 8.13 \\
\hline Calcium (g/kg) & 9.00 & 7.50 & 6.50 & 7.00 & 6.00 \\
\hline Total P (g/kg) & 7.10 & 6.30 & 4.80 & 6.00 & 4.60 \\
\hline Available P (g/kg) & 4.49 & 3.41 & 1.91 & 3.10 & 1.62 \\
\hline
\end{tabular}

PC - positive control, NC - negative control, dig - digestible, ME - metabolizable energy

${ }^{1}$ Contents per kg diet: $4800 \mathrm{IU}$ vit. A; $480 \mathrm{IU}$ vit. D3; $96 \mathrm{mg}$ vit. E ( $\alpha$-tocopherol acetate); $3.6 \mathrm{mg}$ vit. K3; $3 \mathrm{mg}$ vit. B1; 3 mg vit. B2; 30 mg nicotinic acid; $4.8 \mathrm{mg}$ vit. B6; $24 \mu \mathrm{gg}$ vit. B12; $300 \mu \mathrm{g}$ biotin; $12 \mathrm{mg}$ calcium pantothenic acid; $1.2 \mathrm{mg}$ folic acid; $960 \mathrm{mg}$ choline chloride; $60 \mathrm{mg} \mathrm{Zn} \mathrm{(zinc} \mathrm{oxide);} 24 \mathrm{mg} \mathrm{Fe}$ (iron carbonate); $72 \mathrm{mg}$ Mn (manganese oxide); $14.4 \mathrm{mg}$ Cu (copper sulphate-pentahydrate); $0.54 \mathrm{mg} \mathrm{I} \mathrm{(calcium} \mathrm{lodate);} 0.36 \mathrm{mg}$ Co (cobalt- (II)-sulphate-heptahydrate); $0.42 \mathrm{mg}$ Se (sodium selenite); $1.56 \mathrm{~g}$ Na (sodium chloride); $0.66 \mathrm{~g}$ Mg (magnesium oxide) 
Table 2. Composition analysis and phytase activity levels in the experimental diets

\begin{tabular}{|c|c|c|c|c|c|c|c|c|c|}
\hline Feeding phase & Treatment & Dry matter \% & Crude protein \% & Crude fat $\%$ & Crude fibre \% & Crude ash \% & $\mathrm{Ca} \%$ & $\mathrm{P} \%$ & Phytase FTU/kg \\
\hline Starter & & 88.8 & 22.9 & 5.2 & 1.9 & 4.7 & 0.92 & 0.71 & \\
\hline \multirow[t]{8}{*}{ Grower } & $\mathrm{PC}$ & 88.8 & 21.0 & 7.0 & 3.7 & 6.8 & 0.83 & 0.64 & 18 \\
\hline & $\mathrm{NC}$ & 88.8 & 21.1 & 6.8 & 3.6 & 6.2 & 0.70 & 0.49 & 22 \\
\hline & AppAT1-250 & 88.8 & 20.8 & 6.7 & 3.6 & 6.2 & 0.70 & 0.48 & 235 \\
\hline & AppAT1-500 & 89.1 & 20.8 & 6.9 & 3.9 & 6.4 & 0.68 & 0.48 & 440 \\
\hline & АррАТ2-250 & 88.9 & 21.0 & 6.7 & 3.6 & 6.5 & 0.71 & 0.49 & 255 \\
\hline & АрpАТ2-500 & 88.9 & 20.7 & 6.6 & 3.7 & 6.6 & 0.71 & 0.49 & 540 \\
\hline & АррАТЗ-250 & 88.8 & 20.8 & 6.7 & 3.6 & 6.4 & 0.69 & 0.47 & 230 \\
\hline & АррАТЗ-500 & 88.8 & 20.7 & 6.7 & 3.8 & 6.3 & 0.70 & 0.48 & 470 \\
\hline \multirow{8}{*}{ Finisher } & PC & 88.9 & 18.2 & 9.2 & 4.3 & 6.3 & 0.71 & 0.61 & 20 \\
\hline & $\mathrm{NC}$ & 88.9 & 18.0 & 8.8 & 4.5 & 6.1 & 0.60 & 0.46 & 17 \\
\hline & AppAT1-250 & 89.0 & 17.8 & 8.8 & 4.7 & 6.2 & 0.62 & 0.43 & 250 \\
\hline & АрpAT1-500 & 89.0 & 18.1 & 8.7 & 4.6 & 6.1 & 0.62 & 0.48 & 485 \\
\hline & АрpАТ2-250 & 88.9 & 18.0 & 8.8 & 4.5 & 6.1 & 0.64 & 0.46 & 280 \\
\hline & АррАТ2-500 & 89.0 & 17.8 & 8.8 & 4.5 & 6.1 & 0.60 & 0.41 & 560 \\
\hline & АрpАТЗ-250 & 89.1 & 17.9 & 9.0 & 4.7 & 6.0 & 0.60 & 0.38 & 240 \\
\hline & АррАТ3-500 & 89.1 & 17.6 & 8.7 & 4.7 & 6.2 & 0.62 & 0.45 & 510 \\
\hline
\end{tabular}

analysis. During the finisher phase of the experiment (d 31 to 33) in the morning and afternoon, clean excreta (free from feathers, litter and feed) were collected using plastic liners placed in the excreta collection trays (trays measuring $0.6 \times 0.4 \mathrm{~m}$ ) underneath each pen. Excreta samples were immediately frozen until further analysis. For analysis, extra samples were freeze dried, ground and analysed for the indigestible marker $\left(\mathrm{TiO}_{2}\right)$, dry matter, ash, $\mathrm{Ca}$ and P. Performing similar analysis on the finisher feeds, the apparent total tract digestibility (ATTD) of these nutrients was calculated as:

$100-(1-$ (nutrient in faeces/(nutrient in feed $\mathrm{x}$ marker in feed/marker in excreta))) according to the method of Short et al. (1996). All the experiments complied with the guidelines of the Local Ethics Commission (Poland) with respect to animal experimentation and the care of animals under study.

\section{Statistical Analysis}

BW (as pen means), ADG, ADFI and FCR were analysed separately by ANOVA using a randomised block to compare the eight treatment groups. Analysis of variance was performed using ANOVA and means were compared using the Tukey's test (Statistica for Windows, version 13.1). Results were considered significant at $\mathrm{P} \leq 0.05$, and levels of significance between $\mathrm{P}>0.05$ and $\mathrm{P} \leq 0.10$ were considered strong trends.

\section{Results}

The effects of the experimental diets on performance are shown in Table 3. During the study, a total of 29 birds died. No significant differences $(\mathrm{P}>0.05)$ in mortality were seen between the treatment groups, which was less than $5 \%$ and mainly due to Sudden Death Syndrome and cachexia (data not shown).

\section{Body weight and average daily gain}

There were significant $(\mathrm{P}<0.05)$ differences in $\mathrm{BW}$ at $\mathrm{d}$ 21 , with birds in the PC group being heavier $(0.998 \mathrm{~kg})$ than those in the $\mathrm{NC}$ group $(0.886 \mathrm{~kg})$ and in five out of the six phytase supplemented groups (AppAT1-250, AppAT1-500, AppAT2-250, AppAT3-250 and AppAT3-500; Table 3). The AppAT2-500 group had similar body weights to the PC group $(0.985 \mathrm{~kg}$ versus $0.998 \mathrm{~kg})$. Both BW and ADG were significantly $(\mathrm{P}<0.05)$ improved in all phytase-supplemented diet groups compared to the $\mathrm{NC}$ group by the end of the grower period (d 21).

During the finisher period, the ADG for the PC-fed birds and for five of the six phytase supplemented groups (all except AppAT1-250) was significantly $(\mathrm{P}<0.05)$ higher than the ADG of the NC group. At the end of the experiment, at d 35, the BW and ADG over the entire study period (d 6-35) were significantly $(\mathrm{P}<0.05)$ higher in the PC group and in all phytase fed birds compared to those in the NC group.

In early phytase feeding trials, Nelson et al. (1971) recorded a 33.3\% improvement in body weight gain when they added $0.4 \%$ crude phytase (from $A$. ficcum NRRL 3135) to a corn and soybean meal-based broiler diets containing $0.24 \%$ phytate phosphorus. Closer in response to the current data, Sebastian et al. (1996) showed that 600 phytase units/ $\mathrm{kg}$ in a low $\mathrm{P}$ feed increased $(\mathrm{P} \leq 0.05)$ body weight by $13.2 \%$ in males and $5.8 \%$ in females at $21 \mathrm{~d}$ of age, which was comparable 
Table 3. Performance of broiler chickens aged 5, 6-21, 22-35 and 6-35 days old, fed diets varying in $\mathrm{Ca}$ and $\mathrm{P}$ levels, phytase variant and inclusion level

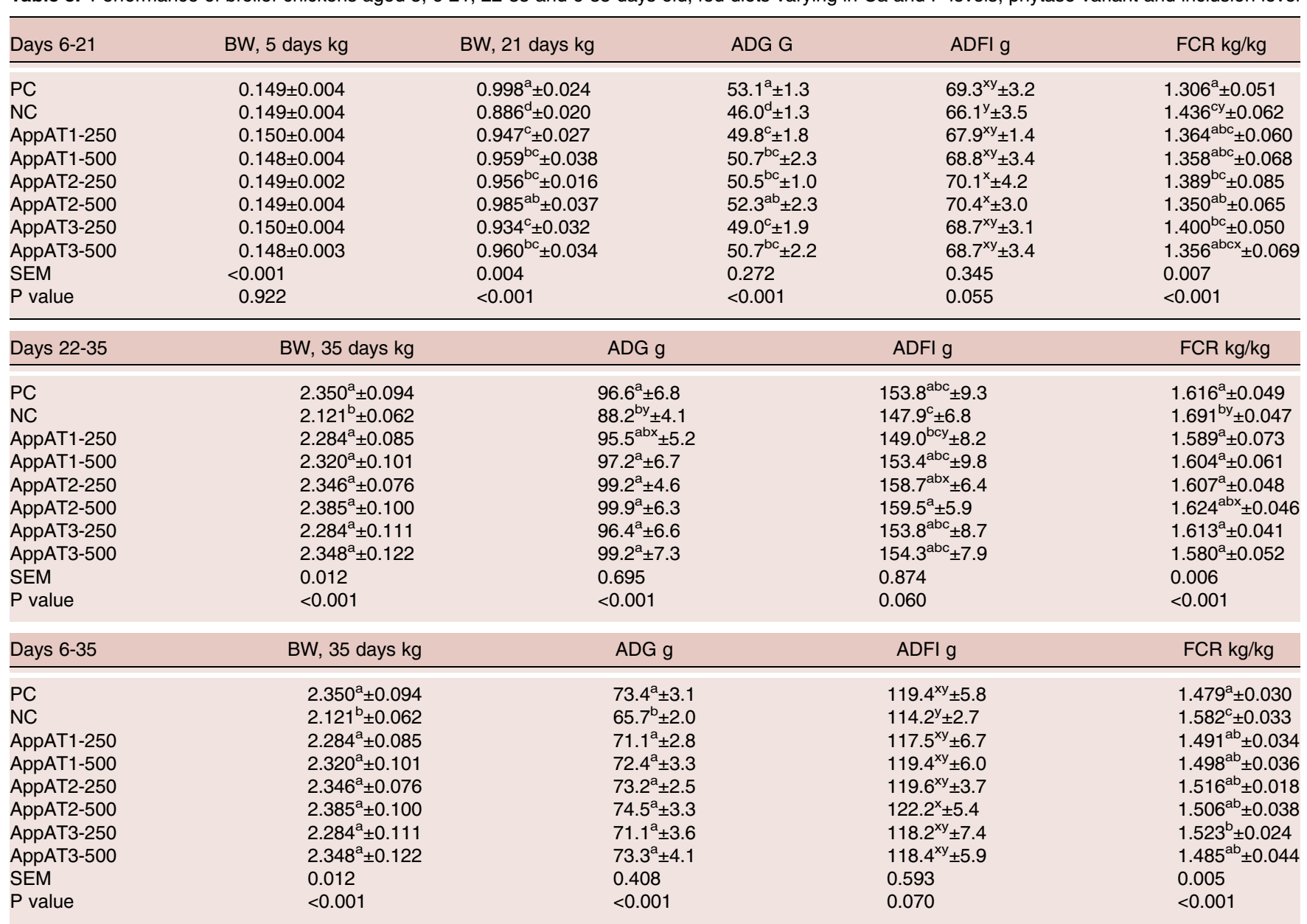

No. replicates $=96$ (12 replicates of 11 birds/treatment); SEM = Standard Error Mean; $B W=$ body weight; $A D G=$ mean daily gain; $A D F I=$ mean daily feed intake; $F C R=$ feed $/$ gain . Values in same columns with no common superscript $(a, b, c, d)$ are significantly different $(P<0.05)$, and with $x, y, z 0.05<P \leq 0.10$ are considered as a near-significant trend. ${ }^{*}$ SEM and $P$ value after arcsine transformation of liveability percentages

to performance in the birds fed the normal P diet. Similar observations for increased body weight with phytase supplementation have been reported abundantly in trials with broiler chickens using different sources of phytases, at both low and high inclusion levels (Gautier et al., 2018; Leyva-Jimenez et al., 2019).

Beeson and associates (2017) reported that body weight gain increased $(\mathrm{P}<0.01)$ linearly with phytase inclusion level $(0,500$ or $1500 \mathrm{FTU} / \mathrm{kg})$ in birds fed a nutritionally adequate positive control group and increased quadratically with phytase inclusion level in birds fed a negative control diet which was marginally deficient in dietary available $\mathrm{P}$ and $\mathrm{Ca}$. Similarly, Dersjant-Li et al. (2018) reported greater body weight gain and lower FCR $(\mathrm{P}<0.05)$ when phytase was supplemented at a higher dose of $1000 \mathrm{FTU} / \mathrm{kg}$, compared to $500 \mathrm{FTU} / \mathrm{kg}$ feed, during both the starter and grower phases.
In contrast, Scholey et al. (2018) concluded that relying on phytase alone could not be recommended in grower diets unless phytase was supplied at doses of 1000 FTU $/ \mathrm{kg}$ or more. Their results illustrated that birds fed a control diet containing no phytase had significantly higher body weight gain $(\mathrm{P}=0.001)$ compared to those fed diets containing 500 or $750 \mathrm{FTU} / \mathrm{kg}$ of phytase, which were low in inorganic $\mathrm{P}$.

\section{Average daily feed intake}

All phytases at all inclusion levels increased ADFI in all feeding phases versus the NC. ADFI differed numerically with near-significant trends seen between treatments during the grower period $(\mathrm{d} 6-21 ; \mathrm{P}=0.055)$, the finisher period ( $\mathrm{d} 22-35, \mathrm{P}=0.06$ ) and the entire trial period (d 6-35; P=0.07; Table 3). The birds given AppAT2-250 and AppAT2-500 diets consumed significantly more 
feed than those in the NC group during the grower (d 6-21), which was, on average, more than those in the other phytase treatments. Birds from the AppAT2-500 group consumed more feed than the AppAT1-250 group, which led to better gain (2.385 kg final BW) compared to the birds fed AppAT1-250 (2.284 kg final BW). Over the entire trial period the AppAT2-500 birds consumed more feed than the NC bird, and hence the final body weight of birds of $\mathrm{NC}$ was the lowest for all dietary treatment groups $(2.121 \mathrm{~kg})$. Rutherfurd et al. (2012) reported that, over a three-week feeding trial, feed intake and corresponding weight gain was lower $(\mathrm{P}<0.05)$ for birds fed an unsupplemented low $\mathrm{P}$ diet compared to an adequate P diet. Sebastian et al. (1996) reported that phytase supplementation overcame $(\mathrm{P} \leq 0.05)$ decreases in feed intake seen when feeding a low $\mathrm{P}$ diet. There was an increase in feed intake and corresponding weight gain $(\mathrm{P}<0.01)$ but no effect $(\mathrm{P}>0.05)$ was seen for FCR in birds fed a phytase-supplemented low $\mathrm{P}$ diet compared to an unsupplemented low $\mathrm{P}$ diet, whereby performance in birds fed the former was equal to the birds fed an adequate P diet. Delezie et al. (2015) found that phytase tended to increase feed intake, mainly when high levels of $\mathrm{Ca}$ (range 8.6 to $6.5 \mathrm{~g} / \mathrm{kg}$ from starter and finisher feed respectively) were applied in the feed. At lower Ca levels (range 7.5 to $4.9 \mathrm{~g} / \mathrm{kg}$ from starter and finisher feed respectively) no such effect was observed.

\section{Feed conversion ratio}

Significant differences between treatments during the grower period (d 6-21) were seen for FCR, with the NC group exhibiting the worst FCR numerically, and the PC and AppAT2-500 groups having significantly $(\mathrm{P}<0.05)$ better FCR compared to the NC group (Table 3). During the finisher period (d 22-35) the FCR of the birds fed the PC and all of the phytase treatment groups (except AppAT2-500) were significantly $(\mathrm{P}<0.05)$ lower than the FCR for the NC group. Over the entire trial period, the FCR in the PC group was significantly $(\mathrm{P}<0.05)$ better compared to birds in the NC and AppAT3-250 groups. All phytase treatment groups had significant improved FCR vs. the NC fed birds.

In contrast with the current findings, Sebastian et al. (1996) did not see any advantages in FCR in their phytase study. This agreed with data from Simons et al. (1990) who did not find any significant improvements in FCR in broilers fed a corn-soya bean diet supplemented with phytase. However, Walk et al. (2012) showed that, although ADFI and BW gain were not affected by $\mathrm{Ca}$ or phytase addition, FCR improved $(\mathrm{P}<0.05)$ as dietary phytase inclusion increased. Recent studies, with the latest developed commercial phytases, reported inconclusive effects of phytase on FCR, which could be linked the fact that final BW of birds fed the phytase supplemented diets was higher than the negative control group (Delezie et al., 2015; Beeson et al., 2017; Scholey et al., 2018; Leyva-Jimenez et al., 2019). Hence, the published data shows varying degrees or even lack of responses to phytase addition, which probably reflects source and efficacy of the enzymes used.

\section{Bone parameters}

The reduced levels of $\mathrm{Ca}$ and $\mathrm{P}$ in the NC group resulted in significantly lower tibia ash content when expressed on dry matter basis $(40.9 \%$; $\mathrm{P}<0.05)$ compared with the PC group (47.4\%; PC; Table 4). The birds fed the phytase supplemented diets had significantly $(\mathrm{P}<0.05)$ higher tibia ash compared to the NC birds. Those fed the AppAT2-500 and AppAT3-500 diets had statistically similar tibia ash contents to the PC birds.

Walk et al. (2012) studied two levels of dietary Ca from limestone $(1.03 \%$ and $0.64 \%)$ and three levels of phytase $(0,500$ or $5000 \mathrm{FTU} / \mathrm{kg})$ on broiler performance, bone ash, gastro-intestinal $\mathrm{pH}$ and apparent ileal digestibility of $\mathrm{Ca}, \mathrm{P}$ and amino acids. They reported that tibia ash was reduced $(\mathrm{P}<0.05)$ from $41.4 \%$ to $40 \%$ as dietary $\mathrm{Ca}$ decreased but increased with phytase addition $(\mathrm{P}<0.05)$. Chung et al. (2013) reported that bone mineral density was increased in diets containing one of the two different phytases tested across varying inclusion levels, with an average of $9 \%$ improvement in the tibia and $13 \%$ in the femur. Cabahug et al. (1999) supplemented microbial

Table 4. Tibia ash, tibia ash per bone and tibia as percentage dry matter in broiler chickens aged 6-35 days old fed diets varying in Ca and P levels, phytase type and inclusion level

\begin{tabular}{llll}
\hline Treatment & Tibia ash (g) & Tibia ash/bone (\%) & Tibia ash (\%/DM) \\
\hline PC & $2.02^{\mathrm{a}} \pm 0.11$ & $43.9^{\mathrm{a}} \pm 1.3$ & $47.4^{\mathrm{a}} \pm 1.3$ \\
NC & $1.41^{\mathrm{d}} \pm 0.29$ & $37.6^{\mathrm{d}} \pm 1.6$ & $40.9^{\mathrm{d}} \pm 1.8$ \\
AppAT1-250 & $1.79 \mathrm{~b}^{\mathrm{c}} \pm 0.12$ & $41.6^{\mathrm{c}} \pm 1.8$ & $45.1^{\mathrm{c}} \pm 2.1$ \\
AppAT1-500 & $1.83^{\mathrm{abc}} \pm 0.17$ & $41.9^{\mathrm{bc}} \pm 1.4$ & $45.4^{\mathrm{bc}} \pm 1.4$ \\
AppAT2-250 & $1.73^{\mathrm{c}} \pm 0.13$ & $41.4^{\mathrm{c}} \pm 1.2$ & $45.0^{\mathrm{c}} \pm 1.3$ \\
AppAT2-500 & $1.98^{\mathrm{ab}} \pm 0.17$ & $43.4^{\mathrm{ab}} \pm 1.1$ & $47.1^{\mathrm{ab}} \pm 1.2$ \\
AppAT3-250 & $1.63^{\mathrm{cd}} \pm 0.17$ & $41.1^{\mathrm{c}} \pm 1.0$ & $44.6^{\mathrm{c}} \pm 1.1$ \\
AppAT3-500 & $1.82^{\mathrm{abc}} \pm 0.21$ & $42.2^{\mathrm{abc}} \pm 1.4$ & $45.9^{\mathrm{abc}} \pm 1.7$ \\
SEM & 0.026 & 0.226 & 0.026 \\
P value & $<0.000001$ & $<0.000001$ & $<0.000001$ \\
\hline
\end{tabular}

Notes: 12 replicates of two bones/treatment; SEM = Standard Error Mean; Values in same columns with no common superscript; $(\mathrm{a}, \mathrm{b}, \mathrm{c}, \mathrm{d})$ are significantly different $(P<0.05)$, and with $x, y, z-0.05<P \leq 0.10$ are considered as a near-significant trend 
Table 5. Apparent total tract digestibility coefficients in broiler chickens aged 6-35 days old fed diets varying in P levels, phytase type and inclusion level

\begin{tabular}{|c|c|c|c|c|}
\hline Treatment & Dry matter & Ash & $\mathrm{Ca}$ & $\mathrm{P}$ \\
\hline $\mathrm{PC}$ & $67.4 \pm 1.8$ & $30.5 \pm 3.7$ & $45.4^{\mathrm{bcdx}} \pm 2.9$ & $48.9^{\mathrm{ab}} \pm 2.7$ \\
\hline NC & $66.5 \pm 2.7$ & $29.7 \pm 4.4$ & $40.2^{\mathrm{dy}} \pm 5.9$ & $47.1^{\mathrm{b}} \pm 3.8$ \\
\hline AppAT1-250 & $67.5 \pm 2.2$ & $29.3 \pm 4.4$ & $45.5^{\mathrm{bcdx}} \pm 3.1$ & $51.0^{\mathrm{ab}} \pm 3.0$ \\
\hline AppAT1-500 & $67.7 \pm 1.9$ & $29.9 \pm 2.8$ & $51.2^{\mathrm{a}} \pm 4.2$ & $53.5^{\mathrm{ax}} \pm 2.7$ \\
\hline АрpAT2-250 & $67.4 \pm 2.7$ & $30.4 \pm 3.8$ & $48.8^{\mathrm{ab}} \pm 5.8$ & $53.1^{\mathrm{a}} \pm 6.2$ \\
\hline АррАТ2-500 & $66.1 \pm 3.1$ & $30.6 \pm 2.7$ & $48.2^{\mathrm{abc}} \pm 3.5$ & $51.5^{\mathrm{ab}} \pm 4.5$ \\
\hline АррАТЗ-250 & $68.3 \pm 2.6$ & $32.6 \pm 2.5$ & $43.2^{\mathrm{cd}} \pm 3.7$ & $48.5^{\text {aby }} \pm 4.8$ \\
\hline АррАТЗ-500 & $67.7 \pm 2.7$ & $29.0 \pm 2.1$ & $46.7^{\mathrm{abc}} \pm 4.2$ & $51.0^{\mathrm{ab}} \pm 4.9$ \\
\hline SEM & 0.255 & 0.352 & 0.535 & 0.468 \\
\hline$P$ value & 0.488 & 0.272 & $<0.001$ & 0.003 \\
\hline
\end{tabular}

Notes: $\mathrm{n}^{\circ}$ replicates $=96$ (12 replicates of 11 birds/treatment); SEM = Standard Error Mean; Values in same columns with no common superscript (a,b,c,d) are significantly different $(P<0.05)$, and with $x, y, z-0.05<P \leq 0.10$ are considered as a near-significant trend

phytase in a wheat-sorghum-soya bean meal diet containing three concentrations of phytate $\mathrm{P}(2.9,3.7$ and $4.4 \mathrm{~g} / \mathrm{kg}$ diet). Toe ash increased with phytase addition, but was best at the highest concentration of phytic acid, due to a significant phytic acid x phytase interaction. In addition, Gautier et al. (2018) reported increases in bone ash with the inclusion of phytase $(\mathrm{P}<0.01)$ at $1500 \mathrm{FTU} / \mathrm{kg}$, as did Leyva-Jimenez et al. (2019) who reported that all four of the phytase sources tested improved bone mineralisation $(\mathrm{P}<0.05)$ at 14 and 22 days of age. Dersjant-Li et al. (2018) however reported that tibia ash was unaffected by the addition of phytase to a P-sufficient diet, which may have been due to a saturation of bone ash formation in the presence of adequate levels of $\mathrm{Ca}$ and $\mathrm{P}$.

\section{Total tract digestibility}

The phytase inclusion significantly $(\mathrm{P}<0.05)$ increased the Ca digestibility, versus the $\mathrm{NC}$ with the exception of the AppAT1-250 and AppAT3-250 groups (Table 5). The AppAT1-500 group showed significantly $(\mathrm{P}<0.05)$ higher Ca digestibility compared to birds fed the PC diet (51.2\% versus $45.4 \%$ ). Compared to the $\mathrm{NC}, \mathrm{P}$ digestibility was improved for the AppAT1-500 and AppAT2-250 groups.

Ravindran et al. (2000) added phytase (400 or 800 phytase unit $/ \mathrm{kg}$ ) to wheat-sorghum-soybean-rice-pollard based broiler diets containing three levels of phytate-P $(0.29, \quad 0.37$ or $0.44 \%)$. They reported improved $(\mathrm{P}<0.05)$ ileal digestibility of nitrogen ranging from 1.6 to $4.7 \%$ by phytase supplementation. In later work, Ravindran et al. (2008) reported increases in Ca or $\mathrm{P}$ digestibility when dietary phytase was supplemented into broiler diets. Sebastian et al. (1996) reported improvements in $\mathrm{P}$ digestibility, but not $\mathrm{Ca}$ digestibility, when phytase was added to broiler diets. Chung et al. (2013) showed that the addition of dietary phytase increased the apparent retention of $\mathrm{Ca}, \mathrm{Na}, \mathrm{Cu}$ and ileal phytase $\mathrm{P}$ absorption from $32-44 \%$ across various inclusion levels. In a three-week broiler trial, Rutherfurd et al. (2012) used two levels of phytase $(1000$ and $2000 \mathrm{U} / \mathrm{kg}$ ) in low P corn-soya bean meal diets and found that the ileal phytate-P absorption in the low $\mathrm{P}$ corn-soy meals was significantly $(\mathrm{P}<0.05)$ higher with the inclusion of phytase. Apparent ileal total $\mathrm{P}$ absorption and apparent total $\mathrm{P}$ retention were higher $(\mathrm{P}<0.05)$ in the phytase diets. There were no differences $(\mathrm{P}>0.05)$ across treatments for apparent or true ileal CP digestibility. However, there was a difference $(\mathrm{P}<0.05)$ across treatments in apparent ileal digestibility for all of the amino acids tested. Dersjant-Li et al. (2018) determined that, compared to the positive control diet containing no phytase but meeting breeder's recommendations, phytase inclusion (500 or $1000 \mathrm{FTU} / \mathrm{kg}$ ) generally enhanced ileal and total tract digestibility of $\mathrm{P}$ and to a lesser extent $\mathrm{Ca}$. They reported that the ileal digestibility of $\mathrm{P}$ at $\mathrm{d} 10$ and $\mathrm{d} 41$ and of $\mathrm{Ca}$ at $\mathrm{d} 41$ was higher in the $1000 \mathrm{FTU} / \mathrm{kg}$ phytase group compared to the diet supplemented with lower levels.

Differences in results between this study and other peer reviewed papers may be explained by the varying effects which are dependent on the inclusion rate, source of phytase, type of diet, bird characteristics and nutrient content of the diet used in the study (Singh, 2008; Amerah et al., 2014).

\section{Conclusions}

Adding the three different thermostable phytase variants based on AppA2 gene from E. coli (AppAT1, AppAT2 and AppAT3) at 250 and $500 \mathrm{FTU} / \mathrm{kg}$ to the NC diet had significantly beneficial effects on BW and ADG, FCR and tibia ash content over the entire trial period (up to $35 \mathrm{~d}$ of age). Ca digestibility was improved in four 
of the six phytase supplemented groups (AppAT1-500, AppAT2-250, AppAT2-500 and AppAT3-500) and P digestibility was improved in the AppAT1-500 and AppAT2-250 groups. It can be concluded that adding the three phytase variants to a reduced $\mathrm{Ca}$ and $\mathrm{P}$ diet improved performance and bone mineralisation, bringing these parameters back to the same levels as a mineral sufficient diet. For all phytase variants, the inclusion rate of $500 \mathrm{FTU} / \mathrm{kg}$ feed gave better results on performance, tibia ash and digestibility compared to the $250 \mathrm{FTU} / \mathrm{kg}$ dose. Although differences between the three phytase variants on performance and digestibility parameters were not significant, the AppAT2 seems to be the most promising candidate for further evaluation.

\section{References}

Amerah A.M., Plumstead P.W., Barnard L.P. and Kumar A. (2014). Effect of calcium level and phytase addition on ileal phytate degradation and amino acid digestibility of broilers fed corn-based diets. Poultry Science 93: 906-915.

Association of Official Analytical Chemists (AOAC). (2012). Official Methods of Analysis. Edited by AOAC; Washington, DC, USA.

Aviagen (2014). Ross Broiler Management Handbook. www.aviagen.com.

Barrier-Gillot B., Casado P., Jondreville C. and Gatel F. (1996). Wheat-phosphorus availability: I- In vitro study: factors affecting endogenous phytasic activity and phytic phosphorous content. Journal of the Science of Food and Agriculture 70: 62-68.

Beeson L.A., Walk C.L., Bedford M.R. and Olukosi O.A. (2017). Hydrolysis of phytate to its lower esters can influence the growth performance and nutrient utilization of broilers with regular or super doses of phytase. Poultry Science 96: 2243-2253.

Cabahug S., Ravindran V., Bryden W.L. and Selle P.H. (1999). Response of broilers to microbial phytase supplementation as influenced by dietary phytic acid and non-phytate phosphorus levels. I. Effects on broiler performance and toe ash content. British Poultry Science 40: 660-666.

Chung T.K., Rutherfurd S.M., Thomas D.V. and Moughan P.J. (2013). Effect of two microbial phytases on mineral availability and retention and bone mineral density in low-phosphorous diets for broilers. British Poultry Science 54(3): 362-373.

Cowieson A.J., Acamovic T. and Bedford M.R. (2004). The effect of phytase and phytic acid on endogenous losses from broiler chickens. British Poultry Science, 45: 101-108.

Cowieson A.J. and Bedford M.R. (2009). The effect of phytase and carbohydrase on ileal amino acid digestibility in monogastric diets: Complimentary mode of action? World's Poultry Science Journal 65: 609-624.

Cowieson A.J., Wilcock P. and Bedford M.R. (2011). Super-dosing effects of phytase in poultry and swine. World's Poultry Science Journal 67(2): 225-236.

CVB (2018) http://www.cvbdiervoeding.nl/bestand/10501/cvb-feedtable-2018-edition-2.pdf.ashx

Delezie E., Bierman K., Nollet L. and Maertens L. (2015). Impacts of calcium and phosphorus concentration, their ratio, and phytase supplementation level on growth performance, foot pad lesions, and hock burn of broiler chickens. Journal of Applied Poultry Research 24: 115-126.

Dersjant-Li Y., Evans C. and Kumarb A. (2018). Effect of phytase dose and reduction in dietary calcium on performance, nutrient digestibility, bone ash and mineralization in broilers fed corn-soybean meal-based diets with reduced nutrient density. Animal Feed Science and Technology 242: 95-110.

Eeckhout W. and De Paepe M. (1994). Total phosphorus phytatephosphorus and phytase activity in plant feed stuffs. Animal Feed Science and Technology 47: 19-29.

Eeckhout W. and De Paepe M. (1996). In vitro and in vivo comparison of microbial and plant phytase. In: Phytase in Animal Nutrition and Waste Management (Coelho M.B. and Kornegay E.T., Eds.). BASF, New Jersey, pp 237-240.

EN ISO 30024 (2009). Animal feeding stuffs - determination of phytase activity. https://www.iso.org/standard/45787.html

Gautier A.E., Walk C.L. and Dilger R.N. (2018). Effects of a high level of phytase on broiler performance, bone ash, phosphorous utilisation and phytate dephosphorylation to inositol. Poultry Science 97: 211-218.

Kim S.-W., Li W., Angel R. and Proszkowiec-Weglarz M. (2018). Effects of limestone particle size and dietary $\mathrm{Ca}$ concentration on apparent $\mathrm{P}$ and $\mathrm{Ca}$ digestibility in the presence or absence of phytase. Poultry Science 97: 4306-4314.

Kozłowski K, Jankowski J, and Jeroch H. (2009). Efficacy of different phytase preparations in broiler rations. Polish Journal of Veterinary Sciences 12: 389-393.

Kozłowski K, Jankowski J, and Jeroch H. (2010). Efficacy of different levels of Escherichia coli phytase in broiler diets with a reduced P content. Polish Journal of Veterinary Sciences 13: 431-436.

Lei X.G. and Stahl C.H. (2001). Biotechnological development of effective phytases for mineral nutrition and environmental protection. Applied Microbiology Biotechnology 57: 474-481.

Leyva-Jimenez H., Alsadwi A.M., Gardner K., Voltura E. and Bailey C.A. (2019). Evaluation of high dietary phytase supplementation on performance, bone mineralization, and apparent ileal digestible energy of growing broilers. Poultry Science 98: 811-819.

Nelson T.S., Shieh T.R., Wodzinski R.J. and Ware J.H. (1971). Effect of supplemental phytase on the utilisation of phytate phosphorus by chicks. Journal of Nutrition 101: 1289-1294.

Council NR (NRC) (1994). Nutrient Requirements of Swine: Eleventh Revised Edition [Internet]. Washington, DC: The National Academies Press. Available from: https://www.nap.edu/catalog/13298/nutrientrequirements-of-swine-eleventh-revised-edition

Ravindran V., Carbahug S., Ravindran G., Selle P.H. and Bryden W.L. (2000). Response of broiler chickens to microbial phytase supplementation as influenced by dietary phytic acid and non-phytate phosphorous levels. II. Effects on apparent metabolisable energy, nutrient digestibility and nutrient retention. British Poultry Science 41: 193-200.

Rodriguez E., Han Y. and Lei X. (1999). Cloning, sequencing, and expression of an Escherichia coli Acid Phosphatase/Phytase Gene (appA2) isolated from pig colon. Biochemical and Biophysical Research Communications 257: 117-123.

Rutherfurd S.M., Chung T.K., Thomas D.V., Zou M.L. and Moughan P.J. (2012). Effect of a novel phytase on growth performance, apparent metabolizable energy and the availability of minerals and amino acids in a low-phosphorous corn-soya bean meal diet for broilers. Poultry Science 91: 1118-1127.

Scholey D. V., Morgan N. K, Riemensperger A., Hardy R. and Burton E.J. (2018). Effect of supplementation of phytase to diets low in inorganic phosphorus on growth performance and mineralization of broilers. Poultry Science 97: 2435-2440.

Sebastian S., Touchburn S.P., Chavez E.R. and Lague P.C. (1996). Efficacy of supplemental microbial phytase at different dietary calcium levels on growth performance and mineral utilisation of broiler chickens. Poultry Science 75: 1516-1523.

Simons P.C.M., Versteegh H.A.J., Jongbloed A.W., Kemme P.A., Slump P., Bos K.D., Wolters M.G.E., Beudeker R.F. and Verschooor G.J. (1990). Improvement of phosphorus availability 
by microbial phytase in broilers and pigs. British Journal of Nutrition 64 : 525-540.

Singh P.K., Khatta V.K. and Thakur R.S. (2003a). Effect of phytase supplementation in maize based diet on growth performance and nutrients utilisation of broiler chickens. Indian Journal of Animal Sciences 73(4): 455-458.

Singh P.K., Khatta V.K., Thakur R.S., Dey S. and Sangwan M.L. (2003b). Effects of phytase supplementation on the performance of broiler chickens fed maize and wheat-based diets with different levels of non-phytate phosphorus. Asian-Australasian Journal of Animal Sciences 16(11): 1642-1649.

Singh P.K. (2008). Significance of phytic acid and phytase in chicken nutrition. World's Poultry Science Journal 64(4): 553-580.

Short F.J., Gorton P., Wiseman J. and Boorman K.N. (1996). Determination of titanium dioxide added as an inert marker in chicken digestibility studies. Animal Feed Science and Technology 59(4): 215-221

Walk C.L., Bedford M.R. and McElroy A.P. (2012). Influence of limestone and phytase on broiler performance, gastrointestinal $\mathrm{pH}$ and apparent ileal nutrient digestibility. Poultry Science 91: 1371-1378.

Walk C.L., Bedford M.R., and Olukosi O.A. (2018). Effect of phytase on growth performance, phytate degradation and gene expression of myo-inositol transporters in the small intestine, liver and kidney of 21 day old broilers. Poultry Science 97: 11551162.

Walk C.L., Venkata S. and Rama R. (2019). High doses of phytase on growth performance and apparent ileal amino acid digestibility of broilers fed diets with graded concentrations of digestible lysine. Journal of Animal Science 97: 698-713. 